\title{
La mirada oblicua o el hallazgo de lo visible
}

\author{
Norma GARZA SALDÍVAR \\ Universidad Autónoma de la Ciudad de México
}

\begin{abstract}
Este trabajo busca explorar las manifestaciones literarias de una mirada oblicua. Mirada que implica hablar de aquello que el ojo ya no es capaz de percibir, lo que queda más allá de lo visible. Esta parte - la que escapa a toda síntesis - es la que posibilita la auténtica alteridad. Quizá de ahí el interés de José Saramago por una mirada oblicua, y el interés de este trabajo por explorar las posibilidades de una novela oblicua. Mirada como ejercicio del pensamiento, de la memoria y la escritura que quiere regresar hacia lo que el ojo de Occidente ya ha mirado para despojarlo de la inercia de una sobrevisualización.
\end{abstract}

PALABRAS CLAVE: Saramago, mirada, oblicuo, novela, alteridad.

This work seeks to explore the literary manifestations of the oblique gaze. A gaze that implies something that the eye is not capable of perceiving, what remains beyond the visible than what is visible. This is what escapes from a synthesis, what enables the authentic otherness. From here may comes José Saramago's interest for an oblique gaze, and the interest in this work to explore the possibilities of an oblique novel. This gaze as an exercise of thought, of memory, and the act of writing that goes back to what the Western eye has already seen, so as to remove the inertia of an over visualization.

KEY WORDS: Saramago, gaze, oblique, novel, otherness.

En sus Seis propuestas para el próximo milenio, en la que lleva por título "Visibilidad", Italo Calvino escribe:

Hubo un tiempo en que la memoria visual de un individuo se limitaba al patrimonio de sus experiencias directas y a un reducido repertorio de imágenes reflejadas por la cultura; la posibilidad de dar forma a mitos personales nacía del modo en que los fragmentos de esa memoria se combinaban entre sí, ensamblándose de maneras inesperadas y sugestivas. Hoy la cantidad de imágenes que nos bombardea es tal que no sabemos distinguir ya la experiencia directa de lo que hemos visto unos pocos segundos en la televisión. La memoria está cubierta por capas de fragmentos de imágenes, como un depósito de desperdicios donde cada vez es más difícil que una figura entre tantas logre adquirir relieve (2005: 98). 


\section{$142 \square$ LA MIRADA OBLICUA O EL HALLAZGO DE LO VISIBLE}

Si bien Calvino se refería al peligro que acecharía el perder la facultad de distinguir entre las imágenes y la experiencia directa, Saramago se refiere, en múltiples lugares de su obra, al peligro que acecharía el perder la facultad de mirar y detenerse frente a lo que se tiene enfrente, sumergidos en ese bombardeo de imágenes en el que se pierden en muchos sentidos las distinciones y diferencias. De ahí su insistencia en algunas de sus novelas de reparar en los peligros y las consecuencias del ya no mirar la realidad o, lo que es peor, del pensar que porque se tienen ojos es posible mirar.

Recordemos su novela Ensayo sobre la ceguera que expone la alegoría de la ceguera humana, imponiendo así la necesidad de confrontar desde otro sitio esa ceguera que se ha instalado en el ojo que mira. El final de la novela y también de la epidemia contagiosa llamada "ceguera blanca" es el principio del reconocimiento de que el ojo aun viendo ya no es capaz de reconocer lo que ve, y la mujer del médico, la única que logra no contagiarse dice: "Creo que no nos quedamos ciegos, creo que estamos ciegos, Ciegos que ven, Ciegos que, viendo, no ven" (373).

En esta novela, los personajes (una pequeña muestra de una humanidad agobiada por la demasiada presencia de lo inmediato) son despojados de sus espacios conocidos y hundidos en las circunstancias más precarias, buscan entonces satisfacer sus necesidades más elementales. Con un cuerpo cada vez más exhausto y aniquilado, estos hombres y mujeres son víctimas de una ceguera contagiosa; epidemia que es necesario poner en cuarentena. El lugar de encierro es nada menos que un viejo manicomio: demencial laberinto que arrastra a los internos a aferrarse a un mínimo espacio que a toda costa tendrán que defender, para probar más que la lucidez la fuerza; más que la dirección cotidiana de una vida, el sobresalto, el desasosiego por un instinto de sobrevivencia. Así, hasta que una energía ya desgastada o una ceguera ya generalizada rompe las fronteras entre el adentro y el afuera, entre lo visible y lo invisible, entre el yo y el otro. Los espacios se confunden en una misma locura, en la que casi todos se hunden en la más clara oscuridad de una civilización que vive las consecuencias de su barbarie. En efecto, Calvino, como creo que también Saramago, al ser hijos de la "civilización de las imágenes", como se nombra Calvino, no trataban de negar las imágenes o su poder, sino de reconocer sus posibilidades, sobre todo en esta época en donde el trabajo con ellas permite el poder reciclarlas y usarlas en nuevos contextos y con otros significados, lo que abre nuevas formas de ver la realidad o de utilizar recursos narrativos para las imágenes y acentuar su extrañamiento. Sin embargo, veían también que en medio de ese remolino de imágenes en el que ahora nos movemos o, mejor, que nos mueve, existe el peligro de quedarnos ciegos frente a la experiencia directa de la singularidad, o frente al otro que ya no logra adquirir relieve, forma o nombre. A veces todo parece hundirse justamente en ese depósito de desperdicios del que hablaba Calvino que, por otro lado, es un depósito que ya no queremos ver, que dando vuelta a la página como damos vuelta al rostro porque estamos hastiados, saturados, enajenados, nos convertimos en presas fáciles para olvidar, para no pensar finalmente, para ya no mirar.

Así, en el centro de esa catástrofe que se narra en el Ensayo sobre la ceguera se forma un pequeño grupo de personas alrededor de la única mujer que conservará la 
vista, todos en busca de comida y de un sitio en donde dormir: "Volvemos a la horda primitiva, dijo el viejo de la venda negra, Con la diferencia de que no somos unos cuantos millares de hombres y mujeres en una naturaleza inmensa e intacta, y sí millares de millones en un mundo descarnado y consumido, Y ciego, añadió la mujer del médico" (292). Este grupo será el protagonista que se encuentra en el umbral de la destrucción: entre la pérdida del agua, de la energía eléctrica, la lucha por la comida y el incesante deambular de un lado a otro buscando algo a qué aferrarse. Todo ello en un ambiente de indiferencia por el que está al lado, ciegos guiados por la ley del más fuerte o por una ceguera más poderosa $\mathrm{y}$, sobre todo, envueltos en una violencia que poco a poco se va gestando en nombre de la sobrevivencia; como siempre suele justificarse, una violencia en nombre de dios, de la libertad o de una "guerra humanitaria", y que no es sino guerra y destrucción en nombre del miedo y el terror.

Para Saramago la mirada oblicua es la que está atravesada por el error, la duda y la sospecha; es la que pone en cuestión lo que se mira o la que hace pensar en la posibilidad de otra respuesta a lo establecido, pensar que no hay verdades definitivas. Como dice Albert Camus (1981: 94): pensar no es unificar, hacer familiar la apariencia bajo el rostro de un gran principio. Pensar es volver a aprender a ver, a estar atentos, es dirigir la conciencia, y hacer de cada idea y de cada imagen, a la manera de Proust, un lugar privilegiado. Así parece exponerlo Saramago en su libro Viaje a Portugal: "Es necesario ver lo que no fue visto, ver otra vez lo que ya se vio, ver en la primavera lo que se vio en verano, ver de día lo que se vio de noche, con sol donde primeramente la lluvia caía, ver el trigal verde, el fruto maduro, la piedra que cambió de lugar, la sombra que aquí no estaba" (1992: 258).

Vivimos en un mundo que se caracteriza por la explosión desbordante de la imagen; imágenes que abarcan todos los ámbitos de la cultura: el religioso, el artístico, el publicitario, el político, etcétera. Nos encontramos así en una época que exalta de manera exacerbada el sentido de la mirada. El problema está quizá no en el objeto que se mira, sino en quién mira y cómo mira; es decir, en el sujeto que capta el bombardeo de imágenes, quizá un sujeto que ya no participa de aquello, sino que se ha convertido él mismo en depósito de imágenes que sabemos encierran situaciones, personas, eventos, catástrofes. Un espectador más del espectáculo del mundo, porque quizá en esta sociedad capitalista de principios de siglo y de milenio, la mirada ha perdido su capacidad de reconstruir y nombrar de otra manera lo que se mira y se ha sometido simplemente a su mandato.

Por otra parte, José Saramago recorre los acontecimientos sociales, políticos y culturales desde el margen y la periferia de los hechos, desde otro lugar; y, probablemente, el género novelístico sea para el escritor portugués la forma más oblicua de abordar la realidad y aquello que nos rodea. Porque él intuye que los textos que pueden hablar directamente de las cosas corren el peligro de traicionar, en algún momento, aquello de lo que están hablando. En el deseo de definir y tematizar se excluyen inmediatamente otras vertientes de un mismo hecho. En cambio, cuando de manera oblicua se rodea a las cosas para conocerlas, no se pueden detener en una definición, sino que 
siempre queda algo por decir, una fisura en la palabra para que la memoria y la imaginación de los otros la sigan reconstruyendo. Así, podemos hablar de dos tipos de miradas: la directa, recta y derecha, frente a la oblicua, sesgada y atravesada, y de ahí quizá formular también una escritura oblicua. Una narración oblicua que nos conduciría, no a la oscuridad o a la claridad de los hechos, sino al claroscuro; no a la narración lineal, sino al desvío y al incesante errar.

El mismo autor apunta que la mirada tiene "que dar la vuelta a las cosas para entenderlas, tiene que ser una mirada circular. Todo lo que digamos que conocemos con una sola mirada se puede decir que no lo conocemos o conocemos una parte" (Entrevista con Silvia Lemus, T. V., Canal 22, mayo de 1997). Esa mirada oblicua es aquella que nos permite ver lo que normalmente no vemos, o también, es la forma de "decir no" a lo que parece claro y evidente; por ello, "hay que dar la vuelta a las cosas para conocer las cosas", aunque sepamos que el dar la vuelta no significa cerrar el círculo sino abrir la espiral del conocimiento.

Si bien Saramago recurre en algunas de sus novelas a la oposición de fuerzas, de poderes, de circunstancias y valores, en otras, y reforzado por su mirada oblicua, opta por la digresión, el discurrir y la errancia. El par alegórico ceguera-mirada no se establece tanto como oposición, sino como diferencia. Hay intercambios y configuraciones que ponen en evidencia el mundo interior y el exterior de algunos de los personajes; y entre ambas polaridades, la tensión del claroscuro. Se alegoriza el entrecruzamiento o quiasmo de los dos tipos de miradas: la directa y la oblicua. Quizá por ello, para Saramago la mirada oblicua implica la otra parte, aquella a la que hace referencia Maurice Blanchot: la que deja de permanecer en la seguridad de las formas o en la superficie de las cosas, la que trasciende la representación, la que, finalmente, penetra en lo más interior, es decir, en lo más invisible ( $c f$. Blanchot, 1992: 128).

Como sucede en el Ensayo sobre la ceguera, pues en medio de la degradación de la condición humana, el signo visible que le pone nombre a esa deshumanización es, paradójicamente, la falta del nombre de los personajes. En ese confinamiento de personas siempre vigiladas, donde todos sufren la misma condición de víctimas de una ceguera que se manifiesta de distintas formas, sólo existen la chica de las gafas oscuras, el niño de los ojos estrábicos, el viejo de la venda negra, el primer ciego, etcétera: ciegos sin nombre, donde unos fungen como opresores de sus mismos compañeros; otros se resignan a vivir en medio de aquel mal, y otros menos, se resisten para no contaminarse totalmente de aquella enfermedad. Quizá lo que salvó al pequeño clan de ciegos guiados por la mujer del médico fue que nunca se acostumbró a vivir en ese estado de horror y de miseria; ciegos que nunca se olvidaron de su propia ceguera. En la pérdida del nombre y en el largo recorrido hacia ningún lado, pueden reconocer que dentro de ellos hay algo que no tiene nombre y que eso es lo que los hace ser.

El escritor portugués logra que el acontecimiento más insignificante se abra a la perplejidad de la mirada en una proyección heterogénea que impide la identificación entre el que mira y lo mirado; más bien, hace que su acercamiento a la realidad sea 
de manera oblicua, como un constante desplazamiento, no solamente para dar la vuelta a las cosas, sino también para completar de nueva cuenta lo que se ve. Con esa mirada, pues, Saramago mira, en algunas de sus novelas, la historia, las relaciones de poder, los evangelios y la condición humana. Y es que el mundo, tal como hoy lo conocemos, está fragmentado en una multiplicidad de temas y acontecimientos de los que solamente nos llega su reflejo a través de medios que oscurecen y hacen más compleja nuestra mirada. El pensamiento no es una mirada que fija la identidad de las formas; "es, como escribe Foucault: gesto, salto, danza, desviación extrema, tensa oscuridad" (1999: 327).

La novela oblicua es la novela imaginada desde otro lado, el lugar de la radical alteridad; es también aquella escritura que incesantemente hace señas de una época, de un pensamiento, pero sobre todo de lo que la mirada hegemónica deja de lado, lo que ya no ve, lo que desecha. Somos lenguaje, pero el lenguaje es ese extraño que reside en nosotros, como diría Maurice Blanchot, una extrañeza que no hace más que señalar. La palabra poética "hace señas", y ésta es la que dice lo que todavía "está-no-dicho"; quizá porque la novela hace señas de lo que todavía no somos, es decir, del ser como posibilidad (1992: 139-140). Descifrar nuevos espacios en la extrañeza que acecha a cada paso de nuestras vidas, en lo ya dicho, es destruir, incomodar o confrontar el nombre que nos dieron, para acercarnos, quizá, cada vez más al nombre que tenemos, o, a lo sin nombre: "dentro de nosotros hay algo que no tiene nombre, esa cosa es lo que somos", dice la chica de las gafas oscuras (Saramago, 1996: 314).

Así como la palabra poética hace señas, también vivimos rodeados de señales, o incluso nosotros mismos somos un sistema de señales, como lo entiende el mismo Saramago. Por ello tendríamos que reconocer también que lo que somos, lo que vemos o lo que leemos no es solamente el movimiento de lo verdadero, de lo representable en el acto o en la letra, sino lo que a partir de eso, de la señal, como huella de una ausencia, nos lleva a un movimiento infinito con lo Otro. La novela para Saramago, como género o mejor como lugar literario, se convierte en la posibilidad de transformar y recibir las palabras de la poesía, del drama, del ensayo, y también de la filosofía y de la ciencia, convirtiéndose de esa manera en "expresión de un conocimiento, de una sabiduría, de una multivisión como lo fueron en su tiempo los grandes poemas de la antigüedad clásica" (Saramago, 1998). Y es que quizá la novela retoma la realidad desde la alteridad para hacer también de la literatura una historia de problemas, como quería Heidegger.

Saramago describe en su novela lo visible como la ceguera a lo Otro, como el recurrir siempre a lo Mismo, a lo conocido, a lo asimilado, por hábito o costumbre. La mirada de la mujer del médico se enfrenta a las consecuencias de esa ceguera cada vez más profunda, para llegar al abismo que está frente a los ojos de los hombres y que éstos no alcanzan a ver. Es el ojo que le sirve al autor como una gran lente por la cual se puede ver la inmundicia, la fragilidad, la crisis del hombre y, por tanto, de una humanidad que ha perdido el sentido. En ella se concentra la totalidad de la verdadera responsabilidad por los otros, la que asume en un momento la terrible tarea de mirar: "Yo soy 
la que nació para ver el horror del mundo", nos dice la mujer del médico. El poder de la visibilidad que rodea la existencia de los hombres les ha arrancado la mirada a lo más lejano, y sólo les ha dejado la mirada a lo más próximo, a un presente que se tambalea entre la ceguera de un pasado y la incapacidad para vislumbrar lo por venir.

La crítica de Saramago a la ceguera de la humanidad se centra en ese ojo capaz de ver solamente en términos de información, de relación o posesión de lo que ve; en cambio, apela por una mirada inquisitiva, inquieta, que busca, pregunta, se detiene y repara en ello. La experiencia de la mirada, como la de la palabra, es esencialmente errante, está siempre fuera de sí misma, en busca de lo Otro. Pero ¿qué es otro en relación con el ser civilizado, con el ciudadano? ¿Qué es otro en relación con la ley, con el derecho institucionalizado, con la racionalidad normalizada? ¿Qué es otro en relación con una sexualidad aceptada, con una nacionalidad legislada, con un poder autoritario, con un mundo globalizado?

Eso Otro es lo que Saramago busca. Recoge así figuras alternas: lo extraño, azaroso, insignificante, desconocido, incierto, marginal; finalmente, se trata de lo desechado por un poder hegemónico para crear esa mirada oblicua que quiere ver el otro lado, la parte donde el ser se descubre a sí mismo con su libertad, soledad, responsabilidad y deseo. No se trata de un acto de buena voluntad, o de rehabilitar al otro y abrirle un espacio en los derechos de un ciudadano, se trata de ejercer el poder de esa alteridad para desestabilizar las fuerzas hegemónicas, los modelos de una lógica racionalista, la ley como principio universal de regulación de la vida, los valores morales, los principios políticos y económicos, la propia identidad, etcétera.

En ese encuentro con lo Otro lo que domina no es el régimen de la comprensión o lo familiar, sino lo incierto y la extrañeza irreductible de culturas, costumbres, rostros, lenguajes y miradas. Como escribe Baudrillard, "jamás dispondremos de pruebas, ni metafísicas ni científicas de este principio de extrañeza y de incomprensibilidad; hay que tomar partido por él" (1990: 42). Tomar partido, puesto que esa radical alteridad nos indica que hay cosas que no percibimos y nos obliga a asumir la existencia de aquello que se queda al margen de nuestra atención.

El mundo existe no como una colección de datos que nuestros sentidos pueden captar y almacenar, haciendo de él una suma de objetos determinados, sino como un horizonte siempre latente de nuestra experiencia. La mirada, entonces, más que acumular o abarcar, busca, abre caminos, deteniéndose en las grietas de este mundo inestable y olvidadizo, para provocar en cada instante un gesto inquisitivo e interrogativo. Quizá no encuentre una palabra mejor para captar lo que Saramago narra que lo que Roland Barthes llama 'incidentes'. Es decir, no se trata de aventuras, ni siquiera de accidentes, sino de incidentes, una palabra más tenue, menos fuerte que el accidente "(pero tal vez más inquietante); es simplemente lo que cae dulcemente como una hoja sobre el tapiz de la vida, es ese pliegue ligero, fugitivo, aportado a la trama de los días, es lo que apenas puede ser notado: una especie de grado cero de la notación, justo lo que hace falta para poder escribir alguna cosa" (1987: 226). Como bien se puede observar en su libro El equipaje del viajero: 
Desde muy lejos se aproximó una brisa que era un murmullo. Movió los tallos tiernos de los hierbajos, las navajas verdes de los cañaverales, hizo ondular en un estremecimiento de luz las aguas pardas de la charca, alzó como una ola las ramas extendidas, envolvió al muchacho en un rápido remolino —y siguió adelante hasta el árbol que lo esperaba. Y subió por el tronco y por las ramas, murmurando siempre. Y las hojas volvieron hacia la luna su faz oculta, y todo el árbol se cubrió de blanco hasta la rama más alta. Y a los ojos deslumbrados del muchacho, trémulo ahora de conmoción y asombro, la aparición del haya milagrosa se mostró en un vertiginoso segundo - que durará mientras dura la vida (1999: 25).

Saramago recupera en sus novelas el acontecimiento como experiencia; esto es, aquella experiencia que está vinculada a un ojo que mira algo determinado, y ese instante entre el que mira y lo mirado se convierte en un momento particularísimo como un aquí y un ahora, en un acto totalmente singular, o como lo llama Saramago, en una “aparición” que "durará mientras dure la vida”, y ¿qué es la aparición sino aquello que nos sale al encuentro?, aquello a lo que simplemente no podríamos sustraernos, una experiencia imposible de negar, pero quizá cada vez menos visible.

Cada vez menos visible por la incapacidad que se vislumbra en la torpeza del pensamiento o, más aún, en la indiferencia para reaccionar frente a lo que nos rodea: "Quién sabe si entre estos muertos no estarán mis padres, dijo la chica de las gafas oscuras, y yo aquí, pasando a su lado, y no los veo, Es una vieja costumbre de la humanidad ésa de pasar al lado de los muertos y no verlos, dijo la mujer del médico" (Saramago, 1996: 340).

Pienso en la literatura como esa forma otra de mirar al mundo, mirar lo que decimos, decir lo que vemos, aun sabiendo, como dice Deleuze, que "lo que se ve no coincide nunca con lo que se dice, por más que uno se esfuerce en decir lo que ve" (2005: 72). Quizá esta no coincidencia entre el ver y el decir es lo que caracteriza a la novela. La novela oblicua es también aquélla imaginada desde otro lado, el lugar de la radical alteridad: la pérdida o la ausencia, lo que ya fue, lo que todavía no está o lo que será; en este sentido, se trata también de la memoria y del deseo recuperados como escritura. No es un espacio de afirmación de la propia identidad, un lugar fácil, cómodo, desde el cual mirar, sino la puesta en cuestión de lo que es.

En este sentido, Saramago habla de una ética de la mirada que implica, de manera ineludible, hablar de aquello que el ojo ya no es capaz de percibir, o de lo que está ahí pero ya no vemos porque nos hemos acostumbrado a ello. Nos hemos quedado con lo que nos han dicho, con lo conocido y aprendido de la realidad; y quizá ya de tan vista y conocida, hemos perdido el reverso de las cosas, y "es esa parte, la que escapa a toda síntesis", la que posibilita la auténtica alteridad. Es necesario establecer grietas, llegar al límite, plantearse nuevas preguntas, encontrar, como diría Deleuze, no una identidad sino una diferencia, escapar al modelo ideal para mostrar mejor las máscaras de la razón occidental.

La ansiedad del mundo contemporáneo, la cancelación cada vez más del espacio privado, la indiferencia a la corporeidad del otro, en suma la soledad que se ha agudizado, paradójicamente, en un mundo más globalizado forman parte del amplio espectro 
que abarca la mirada de José Saramago. Mirada a lo singular que quiere abrirse a una dimensión universal. La condición humana es vista así por el prisma histórico, político y sociológico del escritor portugués, que se postra en la mirada literaria para tener desde ahí la perspectiva de una realidad que parece escapársele al ojo ya habituado, ya ensimismado, enceguecido por la demasiada luminosidad de la modernidad.

No se trata de abarcar la realidad con la mirada como un todo, pues esto sería imposible, sino en todo caso de regresar a esas parcialidades ya miradas, ya dadas, para no dejarlas como objetos concluidos; y en ese regreso abrir otras maneras de pensar lo Mismo. Walter Benjamin ha escrito que la "sobrenominación", la "charla" y el "parloteo" enmudecen a la naturaleza; y si relacionamos esto con una sobrevisualización, con una excesiva explotación de la imagen, diríamos que ello nos deslumbra de tal forma que nos impide ver la realidad de la naturaleza y del otro. Y si el parloteo lleva al enmudecimiento, el exceso de la visualización, nos conduce a la ceguera. Saramago parece exponer un estado de emergencia, mirar hacia la excepción y no hacia la regla.

Tampoco se trata de transformar el mundo en algo cada vez más visible (esto estaría más cercano a una "espectacularización" del mundo, o de la producción propagandística que se encarga de difundir más y más imágenes), sino más bien en hacer que lo visible no concluya o limite sus posibilidades; abrirlo al cuestionamiento y a la duda, a la heterogeneidad del pensamiento. Esta apertura de lo visible indica "respeto por el derecho a una historia, una transformación de uno mismo y el propio pensamiento que nunca se puede totalizar ni reducir a algo homogéneo [...] es también respeto por aquello que, en todo texto, permanece heterogéneo y puede incluso, como en este caso, explicarse en cuanto al tema de esta heterogeneidad abierta mientras nos ayuda a comprenderlo" (Derrida, 1998: 229).

A través de una propuesta de rebeldía, Saramago quiere recuperar una mirada memoriosa, atenta y creativa para rastrear otros caminos que se han quedado al margen de la mirada hegemónica. Imaginar así otras posibilidades de realidades humanas hace del género novelístico el espacio quizá más rebelde y menos institucional; hace de la novela una forma de resistencia ética hacia el poder dominante que somete lo Otro de la mirada y del lenguaje, es decir, del pensamiento, a lo Mismo. Género que también puede entenderse como liberación de la estrechez moral; novela que a veces es en sí misma el ensayo que posibilita una multiplicidad de redes de sentido, tejida por una mirada que se proyecta hacia el pasado y el porvenir; acercamiento oblicuo a la realidad como una re-visión de las formas de mirar de la humanidad, o mejor de sus múltiples cegueras.

La alegoría de la ceguera nos habla de otra forma de mirar, aquella que nos transporta de las debilidades humanas, de sus arrogancias, su intolerancia, su violencia, a la monstruosidad de espacios concentracionarios. Pero también nos coloca en el territorio de la decisión, del encuentro y el gesto, es decir, de la experiencia con el otro. La estructura alegórica impide toda síntesis totalizadora y posibilita, en cambio, la apertura infinita de la narración, la cual podría ser sólo bordeada por la expresión artística. 
La mirada de la mujer del médico, entonces, se altera, se transforma frente a la infinita ceguera blanca que la mira: “Ojalá no sea fiebre, pensó. No lo sería, sería sólo una fatiga infinita, unas ganas locas de envolverse a sí misma, los ojos, ah, sobre todo los ojos, vueltos hacia dentro, más, más, más, hasta poder alcanzar y observar el interior de su propio cerebro, allí donde la diferencia entre el ver y el no ver es invisible a simple vista" (Saramago, 1996: 184).

Lo innombrable y la invisibilidad existen quizá en la dimensión de una alteridad infinita que traspasa todo lo dicho y lo visible. La mirada saramaguiana quiere descomponerse, desintegrarse, destruirse, dejar de ver, "cerrar los ojos para ver", para mirar con otra mirada: aquella que nos vuelva hacia una intimidad más profunda.

El Ensayo sobre la ceguera muy bien pudiera ser la alegoría de lo que Levinas describe de la historia: "como ceguera a lo Otro y laboriosa procesión de lo Mismo" (1982: 124), y tiene que ver con lo que este filósofo entiende como la relación social con el otro, como una relación "des-inter-esada" (Desposeída del inter-esse, del afán de mantenerse en el propio ser [esse]). Es decir, la salida del ser (Levinas desconfía de la palabra amor, por estar tan degradada) y, por tanto, "la responsabilidad para con el otro, el ser-para-el-otro" es la manera de estar en el mundo y preguntar sobre el ser, la responsabilidad de interrogar es lo propio del ser. La primera característica del ser es estar en tela de juicio; estar ahí es estar en el mundo como ser, al lado de las cosas de las que es necesario cuidar (Levinas, 1994: 50).

La narrativa saramaguiana parece recorrer el ámbito de la mirada desde los ciegos de la caverna de Platón hasta el develamiento del enigma a Edipo. Cuando Saramago recurre a la alegoría de la "ceguera blanca", por ejemplo en su Ensayo sobre la ceguera, trasciende el puro objeto y proyecta otra dimensión con la que violenta la noción de realidad. En efecto, la alegoría no es solamente un recurso estético, es una "forma de expresión", como la escritura o el discurso; se trata de una interpretación del presente. No sólo es un elemento formal de una cierta clase de arte, sino también, más que un concepto retórico o incluso poético, la alegoría alude a la coherencia de una visión del mundo, no a una imagen determinada sino a la pluralidad del sentido.

Escribe Saramago:

\begin{abstract}
Esto me lleva a pensar, que la alegoría es más necesaria hoy para hacer que la gente vuelva a pensar sobre las cosas. [...] no es necesario decir algo más allá de la realidad, porque eso es imposible, pero sí es indispensable iluminar lo que se ve con una luz distinta. Es lo mismo que pasa cuando estamos ante un cuadro, si la luz pasa rozándolo, éste cambia. Sabemos que el cuadro es uno nada más, pero que la manera de iluminarlo efectivamente hace que se vean distintas las irregularidades del pincel o de la tinta. De modo que lo necesario es iluminar las mismas cosas de siempre pero con una luz novedosa (Saramago, 1998a).
\end{abstract}

Para Saramago, la época moderna se ha caracterizado por la apariencia desmedida y por la hipocresía de la imagen convertida en espectáculo, lo que ha reducido la realidad a una mayor invisibilidad y silencio. Con ese exceso y esa desmesura, no de la 
mirada sino de las imágenes, el hombre ha transformado el sentido de sus formas de habitar un sitio. Si bien es cierto que la tecnología y los medios prolongan el alcance de nuestra percepción, ésta no siempre nos acerca a la realidad del mundo; pero creemos que podemos poseer y dominar lo que vemos. Como escribe Levinas, "si se pudiese poseer, captar y conocer lo otro, no sería lo otro. Poseer, conocer, captar son sinónimos de poder" (1982: 25). Quizá en este sentido, Saramago entienda la apariencia de la imagen como una fuerza poderosa para poseer, dominar y captar la realidad. Sugiere, entonces, una errancia continua, un regreso permanente a las cosas, un comienzo siempre nuevo del pensamiento, una mirada oblicua. Las consecuencias éticas no tanto de una ceguera como de una ilusión óptica serían peores, pues el ciego reconoce que necesita del otro para orientarse en el mundo; en cambio, el que está seguro de que ve una realidad capaz de manipularse, poseerse o dominarse, creerá sin dudarlo que lo que tiene enfrente es lo verdadero, cuando esto puede ser tan sólo la sombra de otra cosa, como es el caso del mito de la caverna de Platón.

Los elementos de la costumbre, de la cultura o la historia, Saramago los convierte en signos perturbadores y extraños; los mismos que nos hemos habituado a considerar como no problemáticos, obvios o reconocibles, como signos tan claros y determinantes que ya no requerirían ser puestos en cuestión. Como escribe Imre Kertész: "Es propio del ser humano el deseo de instalarse en su mundo dado como en un hogar. Amaestra sus objetos y conceptos como si fueran animales domésticos. Lo esencial es aferrarse a algo que le haga olvidar su soledad y transitoriedad" (2002: 116). El síntoma de la modernidad, diría el mismo Kertész, ya no es el de habitar un sitio sino el de habituarse a él; lo que significa también acostumbrarse al miedo, a la resignación, a la indiferencia, a la violencia y hasta al aburrimiento.

En esta época donde el ser humano se afirma más por la seguridad y las certezas, por la utilidad y el dominio de las cosas, la literatura debiera descender hacia ese punto donde nada tiene aún sentido, para que mantenga el movimiento, la inseguridad y la desdicha de lo que escapa a toda captación, a todo fin. El artista y el poeta deberían involucrarnos con ese espacio donde todo lo que nos proponemos, lo que hemos adquirido y lo que somos, todo lo que se abre sobre la tierra retorna a lo insignificante, donde lo que se aproxima es lo no serio y lo no verdadero, como si quizá brotara de ahí la fuente de toda autenticidad ( $c f$. Blanchot en Levinas, 2000: 40).

Una mirada oblicua que construya una novela oblicua no puede sino acercarse a la pregunta sobre la realidad inmersa en la interrogación de la literatura misma, como ha apuntado Roland Barthes: "La interrogación de la literatura es entonces con un único y mismo movimiento, ínfima (en relación a las necesidades del mundo) y esencial (puesto que esta interrogación es lo que la constituye). Esta interrogación no es: ¿cuál es el sentido del mundo?, ni quizá tampoco: ¿tiene un sentido el mundo?, sino sólo: he aquí el mundo: ¿hay sentido en él?” (Barthes, 2003: 193). La escritura, entonces, como el ejercicio que nos permite de algún modo situarnos y pensarnos de otra manera; rodear ese sentido del mundo para darle otras formas. 
La literatura sería acaso un intento por oponer una crítica violenta, fulgurante, apocalíptica, que descubra elementos singulares que no puedan reducirse a un sistema representativo, un sistema que pretende eliminar las diferencias que acaso lo ponen en cuestión. El ejercicio de la escritura como un caleidoscopio que recoge cualquier figura, un territorio donde todas las formas hablan, en donde la ausencia y la presencia, la realidad y la imaginación, la crítica y la creación, se van contaminando una de la otra hasta hacerse otra cosa en la escritura. Esbozar el movimiento que se despliega en ese cruce es quizá lo que José Saramago quiere aprehender con su escritura. Un movimiento que lo lleva hacia el fundamento mismo de las cosas, a la historia que se cubre con olvidos y cegueras, y que habrá que ir desentrañando como un proceso arqueológico que se inicia en el hallazgo de lo apenas visible. Quizá un hallazgo que nos acerca de algún modo al compromiso de la literatura, sobre el que ya Saramago se preguntaba:

¿Cómo podremos, insisto, aunque provoquemos la burla de las futilidades mundanas y el escarnio de los señores del mundo, volver a un debate sobre literatura y compromiso, sin que parezca que estamos hablando de restos fósiles? Espero que en un futuro próximo no falten respuestas a esta pregunta y que cada una de ellas, o todas juntas, puedan hacernos salir de la dolorosa y resignada parálisis de pensamiento y acción en que parecemos complacernos (Saramago, 1998a).

Esa parálisis de pensamiento y acción; esa mirada anquilosada en lo Mismo del pensamiento y de la civilización; esa lectura directa y recta de lo acontecido hacen que sea pertinente hablar de lo oblicuo como la posibilidad de tener acceso a otra forma de conocimiento, como aquella que se desprende del género mismo de la novela, que tendría que ver más con la errancia y el extrañamiento, con la radical alteridad.

Mirada que oscila, que penetra en las figuras cambiantes y dispersas. Mirada que quiere recuperar el movimiento de las diferencias. Mirada que ha dejado de mirar, de ser un gesto, una señal, que tan sólo abarca lo que abarca el campo visual, para entonces lograr un comercio de miradas. La mirada del ser en el mundo debe tomar distancia, para ver surgir, como diría Merleau-Ponty, las trascendencias, para poner de manifiesto los hilos intencionales que nos vinculan al mundo, "sólo ello es conciencia del mundo porque lo revela como extraño y paradójico" (Merleau-Ponty, 1984: 13). Saramago opta por el vínculo con lo extraño, pues mantener siempre al otro en su extrañeza y sin ninguna pretensión de verdad garantiza en cierta forma el respeto por lo privado, incluso por lo secreto, en un conjunto social no homogéneo, sino mantenido como una alianza de singularidades, y es que "no hay alteridad sin singularidad, no hay singularidad sin aquí-ahora", escribe Derrida (1998: 45).

Los finales de algunas de las novelas de Saramago son inicios, terminan para comenzar a construirse de nuevo, no concluyen: nada está terminado, al contrario, todo está por hacerse, por decirse, por escribirse. La espiral sigue abierta al igual que la figura de la alegoría o del pensamiento de la alteridad, donde el escritor se abandona a la desmesura del error, del errar y el extravío: "el artista no pertenece a la verdad 
porque la obra es lo que escapa del movimiento de lo verdadero, que de algún modo siempre pone en duda, se sustrae a la significación designando esta región donde nada permanece, donde lo que tuvo lugar no ha tenido, donde lo que recomienza aún no ha comenzado nunca" (Cesar Antonio Molina en prólogo de Saramago, 1997: 21).

En esa propuesta de Italo Calvino, "Visibilidad", de la que hablaba al principio de este ensayo, explica que si incluyó la visibilidad en su lista de valores que se han de salvar, es como "advertencia del peligro que nos acecha de perder la facultad humana fundamental: la capacidad de enfocar imágenes visuales con los ojos cerrados, de hacer que broten colores y formas del alineamiento de caracteres alfabéticos negros sobre una página blanca, de pensar con imágenes" (2005: 98). Lo cual, ciertamente, no significa cerrar lo ojos a la realidad, pero tampoco reproducir las imágenes de ésta como dando un informe de lo que sucede, sino de pensar, de imaginar y construir con esos caracteres las páginas que finalmente serán una manera de transfigurar el mundo sensible de la experiencia en imaginación literaria, donde la visualización se convierte en verbalización del pensamiento, en narración de la experiencia. La novela, así, se mueve en el vaivén entre la imagen visual (lectura del mundo) que se hace expresión, y la imagen verbal (lectura del texto) que construye formas de vida con la palabra.

Del mismo modo, Saramago afirma que "el escepticismo del Ensayo sobre la ceguera es radical porque se enfrenta, esta vez directamente, con el mundo"; y más adelante explica que

[...] lo que llamamos estado del mundo es el estado de la desgraciada humanidad que somos [...] ¿Culpas? Oigo decir que todos las tenemos, que nadie puede enorgullecerse de ser inocente, pero me parece que semejantes declaraciones, que aparentemente distribuyen justicia por igual, no pasan, si acaso, de espurias recidivas mutantes del denominado Pecado Original, sólo sirven para diluir y ocultar, en una imaginaria culpa colectiva, las responsabilidades de los auténticos culpables. Del estado, no del mundo, sino de la vida (Saramago, 1997: 592).

¿Cómo tener, pues, desde el espacio académico, universitario, una mirada literaria hacia el mundo que recoja de nueva cuenta lo mirado, un pensamiento imaginativo que cuestione desde otro lugar, una postura que se ejerza en la palabra, una manera de responder literariamente a la banalidad del mundo, a su desmemoria, su pobreza, su ceguera y destrucción? ¿Cómo comprometer a la literatura? Ciertamente no lo sé ni se trata de responder a estas preguntas, sin embargo, cuando pienso el vínculo entre literatura y otras disciplinas pienso que desde la novela y la oblicuidad de la mirada es posible concretar esos cuestionamientos y acercarnos de maneras diferentes a la realidad para ir adquiriendo mayor relieve en las imágenes de la experiencia, para nombrar de otra manera y mirar de nueva cuenta; finalmente para presenciar el hallazgo de lo visible. 
Obras citadas

BARTHES, Roland. 2003. Ensayos críticos. Buenos Aires: Seix Barral. 1987. El grado cero de la escritura. Trad. Nicolás RosA. México: Siglo XXI.

Baudrillard, Jean. 1990. De la seducción. Trad. Elena BenARRoch. México: ReI.

Blanchot, Maurice. 1992. El espacio literario. Barcelona: Paidós.

CALVINO, Italo. 2005. Seis propuestas para el próximo milenio. Trad. Aurora BERNÁRDEZ y César PALMA. Madrid: Siruela.

CAMus, Albert. 1981. Ensayos. Madrid: Aguilar.

Deleuze, Gilles. 2005. La isla desierta y otros textos. Trad. José Luis PARDo. Valencia: Pre-textos.

DerRIDA, Jacques. 1998. Memorias para Paul de Man. Barcelona: Gedisa. FouCAULt, Michel. 1999. El orden del discurso. Barcelona: Tusquets. (Fábula) KERTÉSZ, Imre. 2002. Un instante de silencio en el paredón. Barcelona: Herder. LEVINAS, Emmanuel. 2000. Sobre Maurice Blanchot. Madrid: Trotta. 1994. Dios, la muerte y el tiempo. Madrid, Cátedra 1982. Ética e infinito. Madrid: Visor. (Col. La Balsa de la Medusa, 41)

Merleau-Ponty, Maurice. 1984. Fenomenología de la percepción. Trad. Jem CABANES. Barcelona: Planeta-Agostini.

SARAmago, José. 1999. El equipaje del viajero. Trad. Basilio LosadA. México: Alfaguara.

1998. “Una novela de geografía? Tal vez una nueva novela”. Conferencia. México. 1998a. Entrevista. La Jornada, 157, 8 de marzo. . 1997. Cuadernos de Lanzarote. Trad. Eduardo NAVAL. Madrid: Alfaguara. 1996. Ensayo sobre la ceguera. Trad. Basilio LosADA. Madrid: Alfaguara. 1992. Viaje a Portugal. Trad. Basilio LosADA. Madrid: Alfaguara. 